\title{
Public Assessment for Socioeconomic and Environmental Services of Agroforestry Networks in Kashmir Himalaya, India
}

\author{
M.A. Islam* , P.A. Sofi, G.M. Bhat, A.A. Wani, A.A. Gatoo, \\ Amerjeet Singh and A.R. Malik \\ Faculty of Forestry, Sher-e-Kashmir University of Agricultural Sciences and Technology of \\ Kashmir, Benhama, Ganderbal-191201 (J\&K), India \\ *Corresponding author
}

\section{A B S T R A C T}

Agroforestry is a dynamic ecologically based natural resources management system that diversifies for increased socioeconomic and environmental services for land-users. The study analyzed the prevalent agroforestry practices and their socioeconomic and environmental services to draw up recommendations for sustainable agroforestry development in Ganderbal district of Kashmir Himalaya. Multi-stage random sampling

\section{Keywords}

Socioeconomic, Environmental, Agroforestry,

Kashmir, Himalaya, India.

Article Info

Accepted: 04 September 2017 Available Online: 10 October 2017 was employed to select a sample of 380 households of 10 villages under 3 blocks in the district for field survey. Data were collected using structured interviews and nonparticipant observations. Descriptive and analytical statistics were used for the data analysis. Results indicated that hortisilviagriculture $(26.05 \%)$ is the most prevalent agroforestry system while the agrihorticulture $(2.89 \%)$ is the least practiced agroforestry system. The agroforestry practice comprises planting of 14 categories of ethno-medicagobotanically important plants for livelihood security and ecological sustainability. Weighted Mean Score (WMS) indicated that self-reliance in forest resources (WMS, 2.99) was considered the most important socioeconomic service ranking as $1^{\text {st }}$ whereas the communication exposure (WMS, 1.29) was perceived as least important and ranked as $10^{\text {th }}$. Conversely, biomass production (WMS, 2.80) was observed as the most important environmental service ranking as $1^{\text {st }}$ while the reduction in pest and diseases incidence (WMS, 1.41) was perceived least important and rated as $10^{\text {th }}$. Correlation analysis specified that all the socioeconomic and environmental services were positively and significantly associated with the agroforestry adoption. The effective implementation of agroforestry as key component of community-based policies and programs, the study determined that the socioeconomic and environmental services encouraged adoption by rural farmers making it more viable and sustainable technically.

\section{Introduction}

Agroforestry is the set of land-use practices involving the deliberate combination of trees, agricultural crops and/or animals on the same land management unit in some form of spatial arrangement or temporal sequence (Lundgren and Raintree, 1982).
According to Leakey (1996) the agroforestry is a dynamic, ecologically based natural resources management system that, through the integration of trees on farms and in the agricultural landscape, diversifies for increased social, economic and environmental 
benefits for land-users at all levels. Agroforestry as a land-use option potentially increases livelihood security through simultaneous production of food, fodder, firewood etc. and reduces vulnerability to climate and environmental change (Pandey, 2007; Tiwari et al., 2017). Agroforestry benefits individual landowners and communities alike, because agroforestry combines socioeconomic development with environmental amelioration (Arunachalam and Arunachalam, 2012). Agroforestry practices differ considerably from region to region, community to community and farmer to farmer depending upon the socioeconomic and environmental needs and circumstances (Pant, 2011; Islam et al., 2012). It offers an array of socioeconomic and environmental services which have contributed considerably towards agroforestry adoption, promotion and development (Banyal et al., 2011; Islam and Quli, 2016). It helps in sufficient production of food grains resulting in variation of food habits, stops traditional profession like hunting, gathering forest produces etc. and concentrate only in farming, ensures good and cheap fodder for livestock production, promotes communication exposure as people need contact with field extension functionaries, radio, newspaper etc. to gain more information on agroforestry (Bijalwan et al., 2011; Tiwari et al., 2017). It decreases migration by facilitating increased selfemployment opportunities through interventions such as nursery raising, mat weaving, basket making etc. and contributes to the increased family income (Dagar, 2012; Ashraf et al., 2015). Additionally, the agroforestry practices increases biomass production (fuel wood, fodder, timber, medicine, vegetables, fruits etc.), improves soil conditions such as soil nutrition, moisture content of soil, water-holding capacity etc., improves groundwater recharge, reduces the dependency of people on the natural forests and reduces incidence of pest and diseases
(Gangadharappa et al., 2010; Roy and Tiwari, 2012). Concurrently, the agroforestry moderates micro-climate (reduction of wind speed, stabilization of daily mean temperature, modification of solar radiation, increase of air humidity and decrease of evaporation) and mitigates land degradation through the means of controlling water erosion, soil erosion, reclaiming marginalized land and increasing irrigation and agricultural productivity (Jerneck and Olsson, 2013; Oyebamiji et al., 2013). With their multilayered vegetation structures, agroforestry plantations serve as an important habitat for wild flora and fauna (Tangjang and Arunachalam, 2009).

Agroforestry have become a way of life since time immemorial in Kashmir Himalaya (Islam et al., 2012) and a means to achieve landscape amelioration from an environmental and socioeconomic point of view (Mughal et al., 2000). The general agroforestry systems being practiced traditionally are agrisilviculture, hortisilviculture, hortisilvipasture, agrisilvihorticulture and homegarden (Islam et al., 2017). The woody and fruit tree species mostly grown in agroforestry practices are Salix alba, Populus deltoides, Robinia pseudoacacia, Populus nigra, Morus alba, Juglans regia, Ulmus wallichiana, Ailanthus excelsa, Malus domestica, Pyrus communis, Prunus persica, Prunus armeniaca etc. (Islam et al., 2015). Agroforestry has made remarkable strides in recent years in Kashmir Himalaya, but many challenges remain in terms of its wider application (Islam et al., 2016). Notwithstanding, all its beneficial roles, agroforestry development rate falls far behind the expected (Banyal et al., 2011). The socioeconomic inequalities and disparity in environmental attributes in farming communities play significant differential role in agroforestry promotion and development (Jamala et al., 2013). To promote agroforestry development, a deeper 
understanding of socioeconomic and environmental influences among rural communities is necessary for better agroforestry planning and implementation (Khandagale et al., 2012; Jacobson and Kar, 2013). Hence, it is necessary to identify and measure the range of benefits accrued to the rural people which are not well documented so far. Research is also required to quantify the benefits, to deal with the variability in benefits, to assess the effects of different policies and to examine the impact of agroforestry practices. To make the study viable and sustainable technically and policywise more useful, the researcher also thought it necessary to come up with insightful recommendations. The study aimed to analyze the agroforestry practices of the farmers, assess the socioeconomic and environmental benefits and draw up lessons and recommendations for sustainable agroforestry development in rural communities of Kashmir Himalaya.

\section{Materials and Methods}

\section{Locale of study}

The study was conducted in Ganderbal district of Kashmir Himalaya situated between $34.23^{\circ} \mathrm{N}$ longitude and $74.78^{\circ} \mathrm{E}$ latitude at an altitude of 1650- 3000 meters above MSL. The geographical area of the district is 39304 ha, of which 27.86 percent is forest, 14.65 percent is under non-agricultural use, 8.04 percent is barren and un-cultivable land, 4.55 percent is permanent pastures and other grazing land, 2.48 percent is cultivable waste land and 42.42 percent is net area sown (Anonymous, 2011). The locale experiences both temperate and sub-alpine conditions and is well known for excessive annual rainfall $(700 \mathrm{~mm})$ and temperature varies from $5^{0} \mathrm{C}$ to $20^{\circ} \mathrm{C}$. The district has total human population of $297446 \quad(158,720$ male and 138,726 female), the literacy rate of 59.98 percent, sex ratio of 874 female per 1000 males, family size of 6.62 and population density of 1148 per $\mathrm{km}^{2}$. The district comprises of 84.19 percent of rural and 15.81 percent of urban population living in 136 villages and 44831 households (Census of India, 2011).

\section{Sampling}

The villages and households were selected employing multi-stage random sampling technique (Ray and Mondol, 2004). Three blocks namely, Ganderbal, Lar and Kanagan in the Ganderbal district were randomly selected in the first stage. Ten villages viz., Arhama, Yarmuqam, Manigam, Haripora, Manigam from Lar block, Wayil, Gotli bagh, Nunner, Urpash from Ganderbal block and Wussan from Kangan block were selected in the second stage involving simple random sampling. A total of 380 households were drawn from the sample villages having 5 percent sampling intensity for the field study and the respondents interviewed were either household heads or eldest members.

\section{Data collection}

Data were gathered using a well-structured pre-tested interview schedule and nonparticipant observation (Kumar, 2012). Interview schedule was prepared based on earlier works, reconnaissance survey, and discussion with local people and consultation with the experts. The interview schedule included household level informations on adoption of agroforestry practices and socioeconomic and environmental services of agroforestry networks. To find out the rural people's perception towards the socioeconomic and environmental services of agroforestry networks, ten chief benefits under the socioeconomic and environmental categories were incorporated in the schedule and their degree of importance were measured by a 3-point continuum scale namely, very 
important, moderately important and least important with their respective scores 3, 2 and 1 as per Singha et al., (2006). The ranking of agroforestry values was done from 1 to 10 on the basis of the weighted mean score to determine their relative importance. Under non-participant observation the data were recorded by watching and noting the phenomena.

\section{Data analysis}

The statistical tools viz., frequency (f), percentage $(\%)$, average (x), standard deviation, range, $\mathrm{F}$ test and co-efficient of correlation were applied for data analysis (Snedecor and Cochran, 1967) on MS Excel and Statistical Package for Social Sciences (SPSS) software. The weighted mean score (WMS) for each service was obtained by multiplying the frequencies with their respective scores, adding them up and dividing by the total number of people as follows:

Weighted Mean Score $($ WMS $)=\frac{\sum \mathrm{s}_{\mathrm{i}} \mathrm{f}_{\mathrm{i}}}{-\mathrm{n}^{----}}$

Where,

$f_{i}=$ frequency of the people for $i^{\text {th }}$ item

$\mathrm{S}_{\mathrm{i}}=$ score of the $\mathrm{i}^{\text {th }}$ item

$\mathrm{i}=0,1,2,3,4$ or 5

$\mathrm{n}=$ total number of people

\section{Results and Discussion}

\section{Adoption of agroforestry practices}

Out of the nine existing prominent agroforestry practices, hortisilviagriculture $(26.05 \%)$ is the most prevalent agroforestry system followed by silvihortipastoral (22.11\%), hortisilvipasture (17.89\%), agrisilviculture $(8.95 \%), \quad$ agrisilvipastoral
(6.84\%), hortipastoral (6.05\%), hortisilviculture $\quad(5.26 \%), \quad$ silvipastoral (3.95\%) and agrihorticulture (2.89\%) (Fig. 1). These dominant agroforestry practices of the rural communities are comprised of planting 14 categories of ethno-medicago-botanically important plants viz., fodder (49), fuel (28), vegetable (29), cereals (4), pulses (4), medicinal (8), ornamental (9), fruit (19), timber (7), fencing (7), cottage industry (7), spice (7), edible seed/ nut (4) and oilseed (Islam et al., 2017). These practices interact with each other through their protective and productive functions that benefit the communities as well as the micro-climate (Fouladbash and Currie, 2015). The protective services of agroforestry practices include preventing massive soil erosion, restoring or maintaining soil fertility through nutrient cycling, soil and water conservation, modifying microclimate and providing shade and as live fence and wind breaks (Chakraborty et al., 2015). The agroforestry practices provide socioeconomic services to the farmers through the improved farm productivity (timber, fuel wood, fodder, fruit, food, grains, vegetables etc.) both for the home consumption, cash income and future safety net (Mushtaq et al., 2012).

The categorization of households based on mean (13.25) and standard deviation (3.26) of adoption scores (Table 1) revealed that majority $(52.11 \%)$ of them belonged to medium category followed by low $(26.84 \%)$ and high $(21.05 \%)$ categories. The adoption score ranged from 7.00 to 20.00 . The mean score of agroforestry adoption showed prevalence of people with medium adoption level towards agroforestry practices. The adequate level of adoption could be due to satisfactory knowledge regarding complex agroforestry practices, scientific tree farming, widespread use of primitive indigenous techniques, awareness towards modern agroforestry technologies, appropriate 
extension contact and participation, easiness in availability of quality input materials and tools and availability of financial support (Wani, 2010; Rawat and Vishvakarma, 2011).

\section{Socioeconomic services of agroforestry networks}

The relative ranking of socioeconomic services of agroforestry (Table 2) indicated that the self-reliance in forest resources was perceived highly important by majority $(98.68 \%)$ of the people and ranked $1^{\text {st }}$ (WMS, 2.99). The next utmost $(96.84 \%)$ highly important socioeconomic service of agroforestry was agricultural support which was ranked $2^{\text {nd }}$ (WMS, 2.96). Similarly, a substantial majority $(61.05 \%)$ had considered the service, promotion in livestock production as highly important and assigned the rank $3^{\text {rd }}$ (WMS, 2.27). Regarding the food security most $(67.63 \%)$ of the people have shown moderately important perception and rated it $4^{\text {th }}$ (WMS, 1.86). The income generation was opined as least important among considerable number $(47.90 \%)$ of the people ranking it at $5^{\text {th }}$ (WMS, 1.83). As regards, the other services namely, employment support, nutrition and health security, development of agroforestry industries, reduction in migration and communication exposure the perception of importance were least (44.74-72.89\%) with WMS ranging between 1.81 to 1.29 and thus, the ranks assigned were $6^{\text {th }}$ to $10^{\text {th }}$ respectively. The $F$ value $(p<0.05)$ indicated that the socioeconomic services ranked $1^{\text {st }}$ to $3^{\text {rd }}$ were significantly different with the services ranked between $4^{\text {th }}$ to $7^{\text {th }}$ and $8^{\text {th }}$ to $10^{\text {th }}$.

The agroforestry makes self-reliance in forest resources (fuel wood, fodder, timber, food, medicine and other NTFPs) reducing the dependency of people on the natural forests (Arunachalam and Arunachalam, 2012), provides agricultural support (shade, fertilizer, fencing, compost, soil and moisture conservation, soil improvement etc.) (Bijalwan et al., 2011) and ensures promotion in livestock production through arrangement of good, cheap and nutritious fodder (Pant, 2011; Kumar and Thakur, 2017), that's why people have shown highly important perception towards these services.

On the contrary, the impact of the agroforestry services like food security, income generation, employment support and nutrition and health security among the rural communities in Kashmir Himalaya is comparatively moderate (Islam et al., 2015), hence, these services were considered moderately important. With respect to the other agroforestry services viz., development of agroforestry industries, reduction in migration and communication exposure the exiting agroforestry practices could not bring substantial impact (Islam et al., 2016) that are desirable for the society and hence, adjudged least important.

\section{Environmental services of agroforestry networks}

The rural people's perception of the agroforestry environmental services (Table 3) indicated that the biomass production (WMS, 2.80 ), reduction of pressure on forests (WMS, 2.77) and biodiversity conservation (WMS, 2.72) were considered most important among majority (82.11-74.74\%) of the people and assigned the rank $1^{\text {st }}, 2^{\text {nd }}$ and $3^{\text {rd }}$ respectively.

The environmental services like amelioration of the microclimate (WMS, 2.45), soil fertility improvement (WMS, 2.41), windbreak protection (WMS, 2.27) and ground water recharge (WMS, 1.96) were perceived as most important by $53.95-21.31 \%$ and moderately important by $37.11-52.90 \%$ of the people ranking them as $4^{\text {th }}$ to $7^{\text {th }}$. Likewise, a substantial majority $(66.58-71.84 \%)$ of the 
people contemplated the services viz., pollution reduction (WMS, 1.48), erosion control (WMS, 1.45) and reduction in pest and diseases incidence (WMS, 1.41) as least important and were rated as $8^{\text {th }}, 9^{\text {th }}$ and $10^{\text {th }}$ respectively. The $\mathrm{F}$ statistics $(\mathrm{p}<0.05)$ showed that the environmental services ranked $1^{\text {st }}$ to $3^{\text {rd }}$ were significantly different with the services ranked between $4^{\text {th }}$ to $7^{\text {th }}$ and $8^{\text {th }}$ to $10^{\text {th }}$.

Table.1 Descriptive statistics for agroforestry adoption in Kashmir Himalaya (N=380)

\begin{tabular}{llllllll}
\hline $\begin{array}{l}\text { Category } \\
\text { (Scores) }\end{array}$ & $\begin{array}{l}\text { Households } \\
(\%)\end{array}$ & Mean & Std. Dev. & $\begin{array}{l}\text { 95\% Confidence Interval for } \\
\text { Mean }\end{array}$ & Minimum & Maximum \\
\cline { 3 - 6 } & & & & Upper bound & Lower bound & & \\
\hline Low $(<10.00)$ & $102(26.84)$ & 13.25 & 3.26 & 12.78 & 13.71 & 7.00 & 20.00 \\
$\begin{array}{l}\text { Medium }(10.00 \\
\text { to } 16.51)\end{array}$ & $198(52.11)$ & & & & & & \\
High $(>16.51)$ & $80(21.05)$ & & & & & & \\
\hline
\end{tabular}

Table. 2 Socioeconomic services of agroforestry networks in Kashmir Himalaya (N=380)

\begin{tabular}{|c|c|c|c|c|c|}
\hline \multirow[t]{2}{*}{ Socioeconomic services } & \multicolumn{3}{|c|}{ Perception } & \multirow[t]{2}{*}{ WMS } & \multirow{2}{*}{$\begin{array}{l}\text { Mean } \\
\text { rank }\end{array}$} \\
\hline & $\mathrm{HI}$ & MI & LI & & \\
\hline Self-reliance in forest resources & $375(98.68)$ & $05(1.32)$ & $00(0.00)$ & $2.99^{\mathrm{a}}$ & 1 \\
\hline Agricultural support & $368(96.84)$ & $10(2.63)$ & $02(0.53)$ & $2.96^{\mathrm{a}}$ & 2 \\
\hline Promotion in livestock production & $232(61.05)$ & $126(33.16)$ & $22(5.79)$ & $2.55^{\mathrm{a}}$ & 3 \\
\hline Nutrition and health security & $20(5.26)$ & $171(45.00)$ & $189(49.74)$ & $1.56^{\mathrm{b}}$ & 7 \\
\hline Food security & $35(9.21)$ & $257(67.63)$ & $88(23.16)$ & $1.86^{\mathrm{b}}$ & 4 \\
\hline Development of agroforestry industries & $34(8.95)$ & $103(27.10)$ & $243(63.95)$ & $1.45^{\mathrm{c}}$ & 8 \\
\hline Reduction in migration & $21(5.53)$ & $78(20.52)$ & $281(73.95)$ & $1.32^{\mathrm{c}}$ & 9 \\
\hline Income generation & $118(31.05)$ & $80(21.05)$ & $182(47.90)$ & $1.83^{\mathrm{b}}$ & 5 \\
\hline Employment support & $98(25.79)$ & $112(29.47)$ & $170(44.74)$ & $1.81^{\mathrm{b}}$ & 6 \\
\hline Communication exposure & $07(1.84)$ & 96 (25.27) & $277(72.89)$ & $1.29^{\mathrm{c}}$ & 10 \\
\hline
\end{tabular}

Note: HI= Highly important; MI= Moderately important; LI= Least important; WMS $=$ Weighted mean score; Figures in the parentheses indicate percentages; WMS followed by different superscript letters within the column are significantly different $(\mathrm{p}<0.05)$

Table.3 Environmental services of agroforestry networks in Kashmir Himalaya (N=380)

\begin{tabular}{llllll}
\hline Environmental services & \multicolumn{3}{c}{ Perception } & WMS & $\begin{array}{l}\text { Mean } \\
\text { rank }\end{array}$ \\
\cline { 2 - 4 } & HI & MI & LI & & \\
\hline Biomass production & $312(82.11)$ & $60(15.79)$ & $08(2.10)$ & $2.80^{\mathrm{a}}$ & 1 \\
Soil fertility improvement & $198(52.11)$ & $141(37.11)$ & $41(10.78)$ & $2.41^{\mathrm{b}}$ & 5 \\
Amelioration of the microclimate & $205(53.95)$ & $141(37.11)$ & $34(8.94)$ & $2.45^{\mathrm{b}}$ & 4 \\
Reduction of pressure on forests & $304(80.00)$ & $65(17.11)$ & $11(2.89)$ & $2.77^{\mathrm{a}}$ & 2 \\
Biodiversity conservation & $284(74.74)$ & $87(22.89)$ & $09(2.37)$ & $2.72^{\mathrm{a}}$ & 3 \\
Windbreak protection & $167(43.95)$ & $148(38.94)$ & $65(17.11)$ & $2.27^{\mathrm{b}}$ & 6 \\
Pollution reduction & $55(14.47)$ & $72(18.95)$ & $253(66.58)$ & $1.48^{\mathrm{c}}$ & 8 \\
Ground water recharge & $81(21.31)$ & $201(52.90)$ & $98(25.79)$ & $1.96^{\mathrm{b}}$ & 7 \\
Reduction in pest and diseases incidence & $48(12.63)$ & $59(15.53)$ & $273(71.84)$ & $1.41^{\mathrm{c}}$ & 10 \\
Erosion control & $53(13.95)$ & $66(17.37)$ & $261(68.68)$ & $1.45^{\mathrm{c}}$ & 9 \\
\hline N & & & &
\end{tabular}

Note: HI= Highly important; MI= Moderately important; LI= Least important; WMS $=$ Weighted mean score; Figures in the parentheses indicate percentages; WMS followed by different superscript letters within the column are significantly different $(\mathrm{p}<0.05)$ 
Table.4 Correlation analysis of socioeconomic and environmental services with agroforestry adoption in Kashmir Himalaya $(\mathrm{N}=380)$

\begin{tabular}{|c|c|c|c|}
\hline Socioeconomic services & $\begin{array}{l}\text { Co-efficient of } \\
\text { correlation }(\mathrm{r})\end{array}$ & Environmental services & $\begin{array}{l}\text { Co-efficient of } \\
\text { correlation }(r)\end{array}$ \\
\hline Self-reliance in forest resources & $0.678^{*}$ & Biomass production & $0.652^{*}$ \\
\hline Agricultural support & $0.648^{*}$ & Soil fertility improvement & $0.578^{*}$ \\
\hline Promotion in livestock production & $0.743^{*}$ & Amelioration of the microclimate & $0.571^{*}$ \\
\hline Nutrition and health security & $0.554^{*}$ & Reduction of pressure on forests & $0.509^{*}$ \\
\hline Food security & $0.638^{*}$ & Biodiversity conservation & $0.476^{*}$ \\
\hline Development of agroforestry industries & $0.560^{*}$ & Windbreak protection & $0.460^{*}$ \\
\hline Reduction in migration & $0.532^{*}$ & Pollution reduction & $0.405^{*}$ \\
\hline Income generation & $0.721^{*}$ & Ground water recharge & $0.429^{*}$ \\
\hline Employment support & $0.559^{*}$ & $\begin{array}{l}\text { Reduction in pest and diseases } \\
\text { incidence }\end{array}$ & $0.456^{*}$ \\
\hline Communication exposure & $0.524^{*}$ & Erosion control & $0.472^{*}$ \\
\hline
\end{tabular}

$*=$ Significant at $5 \%$ level of probability

Fig.1 Adoption of agroforestry practices in Kashmir Himalaya $(\mathrm{N}=380)$

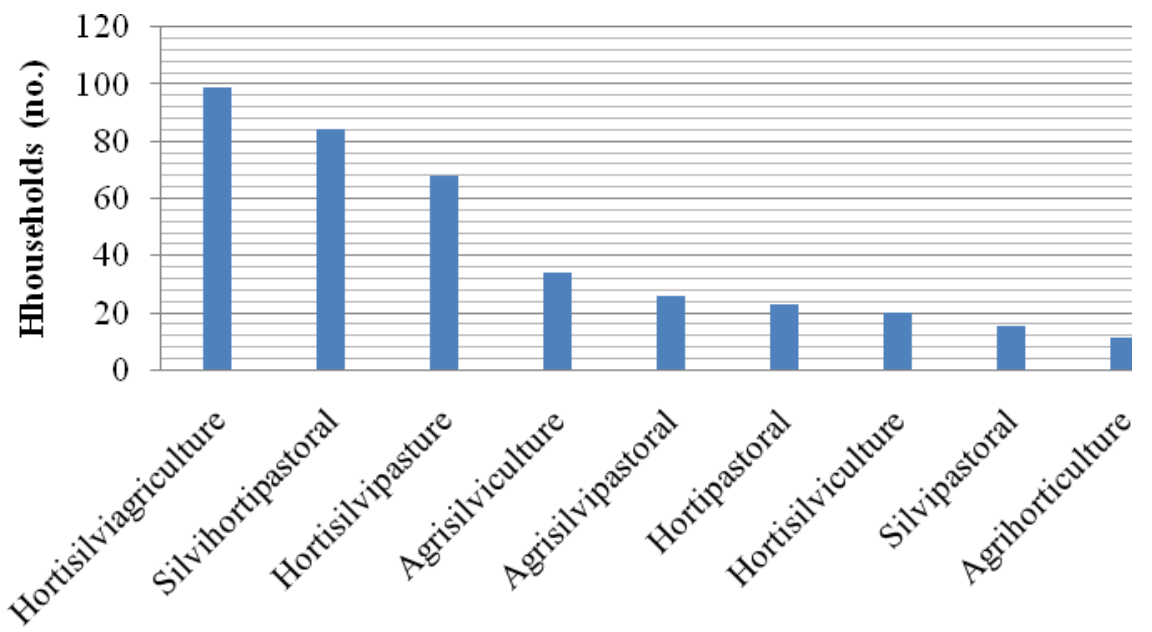

Agroforestry practices

This is a fair reflection because the environmental services which provide tangible benefits that can be easily observable among the rural people were given higher ranking while the services giving intangible benefits which are least observable were ranked lower. The environmental services promoting productive, economic, human and social development were assigned higher values due to their socioeconomic and life supporting impact to the rural societies, which is in consistent with the previous workers (Kareemulla et al., 2009; Bijalwan et al., 2011). Contrary to this, the people rated the environmental services providing only protective functions to the rural populace such as soil and water conservation, erosion control, flood control, reduction in incidence of pests and diseases etc. as low which existed because of its imperceptible benefits (Mfitumukiza et al., 2017). 


\section{Correlation results}

Simple correlation analysis (Table 4) indicated that all the socioeconomic and environmental services had shown positively significant association with the agroforestry adoption. The values of correlation coefficients (r) for the socioeconomic and environmental services worked out were, selfreliance in forest resources (0.678), agricultural support (0.648), promotion in livestock production (0.743), nutrition and health security (0.554), food security (0.638), development of agroforestry industries (0.560), reduction in migration (0.532), income generation (0.721), employment support (0.559) and communication exposure (0.524), biomass production (0.652), soil fertility improvement (0.578), amelioration of the microclimate (0.571), reduction of pressure on forests (0.509), biodiversity conservation (0.476), windbreak protection $(0.460)$, pollution reduction $(0.405)$, ground water recharge $(0.429)$, reduction in pest and diseases incidence (0.456) and erosion control (0.472).

The agroforestry plantation for variety of socioeconomic services is an adaptive century-old indigenous practice of the rural communities in the Kashmir Himalaya (Mughal et al., 2000; Islam et al., 2015). This means that all the people in Kashmir Himalaya needs self-reliance in forest resources, agricultural support, promotion in livestock production, nutrition and health security, food security, development of agroforestry industries, reduction in migration, income generation, employment support and communication exposure.

The studies (Pant, 2011; Islam and Quli, 2016; Verma et al., 2017) also confirmed positively significant association between socioeconomic services and the agroforestry adoption. The adoption of various agroforestry practices besides providing socioeconomic services it offers a range of environmental services namely, biomass production, soil fertility improvement, amelioration of the microclimate, reduction of pressure on forests, biodiversity conservation, windbreak protection, pollution reduction, ground water recharge, reduction in pest and diseases incidence and erosion control which have been realized as potential benefits for livelihood security and ecological stability. The results are in consistent with Islam and Quli (2016), Quli et al., (2016) and Kumar et al., (2017).

The people of the Kashmir Himalaya practice nine prominent agroforestry systems to meet their socioeconomic and environmental needs. These agroforestry practices comprise planting of 14 categories of ethno-medicagobotanically important plants to meet the basic needs besides livelihood security and safety net function of the local populace.

The adequate knowledge regarding complicated agroforestry practices, extensive use of primitive indigenous techniques, scientific know-how regarding tree farming, high awareness towards modern agroforestry technologies, sufficient extension and communication facilities, easy accessibility of quality input materials and tools for agroforestry and financial support overwhelmingly facilitate agroforestry adoption and strengthening. But, this agroforestry adoption is strongly affected by some important socioeconomic and environmental services which associate a positive value. Hence, to promote and develop agroforestry networks further for socioeconomic improvement and environmental sustainability in the Kashmir Himalaya consideration of these services by the policy makers, planners and scientists is crucial. 


\section{Acknowledgement}

Our deep thanks to the people of the sample villages for their co-operation in sharing the information regarding agroforestry. Special thanks to the Interns, Forestry Works Experience, Faculty of Forestry, SKUAST-K, Benhama, Ganderbal, Kashmir for providing support during our field-work.

\section{References}

Anonymous, 2011. Directorate of Economics and Statistics, District Statistics and Evaluation Office Ganderbal, Jammu \& Kashmir.

Arunachalam, K., and Arunachalam, A. 2012. Role of agroforestry in human livelihoods and biodiversity management.. Indian Journal of Agroforestry, 14(1): 97-100.

Ashraf, J., Pandey, R., de Jong, W. and Nagar, B. 2015. Factors influencing farmers' decisions to plant trees on their farms in Uttar Pradesh, India. Smallscale For., 2015, 1-13.

Banyal, R., Masoodi, N.A., Masoodi, T.H., Sharma, L.K. and Gangoo, S.A. 2011. Knowledge and attitude of farmers towards agroforestry practices in north Kashmir- a case study. The Indian Forester, 137(12): 1377-1381.

Bijalwan, A., Sharma, C.M. and Kediyal, V.K. 2011. Socioeconomic status and livelihood support through traditional agroforestry systems in hill and mountain agro-ecosystem of Garhwal Himalaya, India. The Indian Forester, 138(12): 1423-1430.

Census of India 2011. A - 5 State Primary Census Abstract - 2011, India.

Chakraborty, M., Haider, M.Z. and Rahaman, M.M. 2015. Socio-economic impact of cropland agroforestry: Evidence from Jessore District of Bangladesh. Inter. J. Res. in Agric. and For., 2(1):11-20.
Dagar, J.C., 2012. Utilization of degraded lands/ habitats and poor quality water for livelihood security and mitigating climate change. Indian Journal of Agroforestry, 14(1): 1-16.

Fouladbash, L., and Currie, W.S. 2015. Agroforestry in Liberia: household practices, perceptions and livelihood benefits. Agroforestry Syst., 89(2): 247266.

Gangadharappa, N.R., Shivamurthy, M. and Ganesamoorthi, S. 2010. Agroforestry a viable alternative for social, economic and ecological sustainability. My Forest, 41(2): 107-119.

Islam, M.A., and Quli, S.M.S. 2016. Motivation strategy for agroforestry intensification among small holders. Advances in Life Sciences, 5(10): 38783883.

Islam, M.A., Banyal, R., Rai, R. and Singh, P.K. 2012. Determinant factors of agroforestry adoption in north Kashmir. Indian Journal of Social Research, 53(2): 123-129.

Islam, M.A., Masoodi, T.H., Gangoo, S.A., Sofi, P.A., Bhat, G.M., Wani, A.A., Gatoo, A.A., Singh, A. and Malik, A.R. 2015. Perceptions, attitudes and preferences in agroforestry among rural societies of Kashmir, India. Journal of Applied and Natural Science, 7(2): 976983.

Islam, M.A., Qaisar, K.N. and Bhat, G.M. 2017. Indigenous knowledge in traditional agroforestry systems of Kashmir valley: Current challenges and future opportunities. International Journal of Forestry and Crop Improvement, 8(1): 62-71.

Islam, M.A., Sofi, P.A., Bhat, G.M., Wani, A.A., Gatoo, A.A., Singh, A. and Malik, A.R. 2016. Prediction of agroforestry adoption among farming communities of Kashmir valley, India: a logistic regression approach. Journal of Applied 
and Natural Science, 8(4): 2133-2140.

Jacobson, M., and Kar, S. 2013. Extent of agroforestry extension programs in the United States. Journal of Extension, 51(4): 19-26.

Jamala, G.Y., Shehu, H.E., Yidau, J.J. and Joel, L. 2013. Factors influencing adoption of agroforestry among smallholder farmers in Toungo, Southeastern, Adamawa State, Nigeria. IOSR Journal of Environmental Science, Toxicology and Food Technology, 6(6): 66-72.

Jerneck, A., and Olsson, L. 2013. More than trees! Understanding the agroforestry adoption gap in subsistence agriculture: Insights from narrative walks in Kenya. Journal of Rural Studies, 32: 114-125.

Kareemulla, K., Rizvi, R.H., Yadav, R.S., Munnaram and Dhyani, S.K. 2009. Agroforestry for rural development cooperatives as viable institutions. Agricult. Situ. India, May, 2009, pp. 6167.

Khandagale, A.S., Taide, Y.B., Deshmukh, H.K. and Thigale, M.B. 2012. Constraints faced by growers in adoption of recommended practices of teak. Indian Journal of Agroforestry, 14(1): 45-48.

Kumar, R., 2012. Research Methodology - A step by step guide for beginners. Dorling Kindersley (India) Pvt. Ltd., New Delhi, India.

Kumar, Y., and Thakur, T.K. 2017. Agroforestry: Viable and Futuristic Option for Food Security and Sustainability in India. International Journal of Current Microbiology and Applied Sciences, 6(7): 210-222.

Kumar, Y., Thakur, T.K., and Thakur, A. 2017. Socio-cultural paradigm of agroforestry in India. International Journal of Current Microbiology and Applied Sciences, 6(6): 1371-1377.

Leakey, R., 1996. Definition of agroforestry revisited. In: Agroforestry today, vol. 8 no: 1.

Lundgren, B.O., and Raintree, J.B. 1982. Sustained agroforestry. In B. Nestel, ed. Agricultural research for development: potentials and callenges in Asia. The Hague, International Service for National Agricultural Research, pp. 3749.

Mfitumukiza, D., Barasa, B. and Ingrid, A. 2017. Determinants of agroforestry adoption as an adaptation means to drought among smallholder farmers in Nakasongola District, Central Uganda. African Journal of Agricultural Research, 12(23): 2024-2035.

Mughal, A.H., Ara, T., and Bhattacharya, P. 2000. Socio-economic aspects of agroforestry in rural Srinagar of Kashmir valley. The Indian Forester, 126(3): 234-240.

Mushtaq, T., Sood, K.K. and Raina, N.S. 2012. Species preferences for fuel wood in Shiwalik Himalayas- Implications for agroforestry plantations. Indian J. Hill Fmg., 25(2): 18-21.

Oyebamiji, N.A., Adedire, M.O., Aduradola, A.M. and Agboola, D.A. 2013. Potential benefits of agroforestry practices on livelihood and environment of farmers in Odeda Local Government, Area of Ogun State, Nigeria. International Journal of Science and Nature, 4(4): 603-607.

Pandey, D.N., 2007. Multifunctional agroforestry systems in India. Current Science, 92(4): 455-463.

Pant, N., 2011. Motivational factors in activities of agroforestry - a case study. The Indian Forester, 137(3): 363-569.

Quli, S.M.S., Islam, M.A. and Singh, P.K. 2016. ECOSAN (Ecological Sanitation) based agroforestry for boosting rural livelihoods. The Indian Forester, 142(9): 862-870.

Rawat, Y.S., and Vishvakarma, S.C.R. 2011. 
Pattern of fodder utilization in relation to sustainability under indigenous agroforestry systems, North-Western Himalaya, India. Environ. We Int. J. Sci. Tech., (6): 1-13.

Ray, G.L., and Mondol, S. 2004. Research Methods in Social Sciences and Extension Education, Kalyani Publishers, New Delhi, 66-76.

Roy, M.M., and Tiwari, J.C. 2012. Agroforestry for climate resilient agriculture and livelihood in arid region of India. Indian Journal of Agroforestry, 14(1): 49-59.

Singha, A.K., Talukdar, R.K. and J.K. Singha. 2006. Maintenance behaviour of forest resources by the people of forest villagers in Assam. Indian Journal of Forestry, 29(1): 47-54.

Snedecor, G.W., and Cochran, W.G. 1967. Statistical Methods. Iowa State
University Press, Ames, Iowa-50010. Tangjang, S., and Arunachalam, A. (2009). Role of traditional homegarden systems in northeast India. Journal of Traditional Knowledge 8 (1): 47 - 50.

Tiwari, P., Kumar, R., Thakur, L. and Salve, A. 2017. Agroforestry for sustainable rural livelihood: A review. International Journal of Pure and Applied Bioscience, 5(1): 299-309.

Verma, P., Bijalwan, A., Dobriyal, M.J.R., Swamy, S.L. and Thakur, T.K. 2017. A paradigm shift in agroforestry practices in Uttar Pradesh. Current Science, 112(3): 509-516.

Wani, N.R., Mughal, A.H., Bhat, G.M., Khan, I.J., Mugloo, J.A. 2010. Vegetation analysis of the afforested bank of Manasbal Lake, Kashmir. Indian Journal of Agroforestry, 12(2): 92-95.

\section{How to cite this article:}

Islam, M.A., P.A. Sofi, G.M. Bhat, A.A. Wani, A.A. Gatoo, Amerjeet Singh and Malik, A.R. 2017. Public Assessment for Socioeconomic and Environmental Services of Agroforestry Networks in Kashmir Himalaya, India. Int.J.Curr.Microbiol.App.Sci. 6(10): 410-420. doi: https://doi.org/10.20546/ijcmas.2017.610.051 